\title{
Breastfeeding and Health Professionals in Britain, New Zealand and the United States, 1900-1970
}

\author{
LINDA BRYDER*
}

Modern medical opinion is almost universally in favour of breastfeeding as the best food for newborn infants. Yet this was not always the case. American social historian Rima Apple has argued convincingly that medical attitudes in the United States undermined breastfeeding in the first half of the twentieth-century. She explains how the concept of "scientific motherhood", successfully promoted by the medical profession during the first half of the twentieth century, "fostered the acceptance of, when not the wholesale commitment to, bottle feeding under physician-supervision". ${ }^{1}$ In her recent book on breastfeeding in the United States, Jacqueline Wolf argues that while many doctors in the United States supported breastfeeding, they inadvertently undermined it by advocating routine feeding and by providing a viable alternative through milk formulas. ${ }^{2}$ Considering the experience of breastfeeding in two further environments, Britain and New Zealand, contributes to the discussion of the role of health professionals in promoting breastfeeding. Doctors in Britain and New Zealand did not promote the move from breast to bottle, as Apple found in America. Nor did they appear to undermine breastfeeding by their advocacy of routine feeding. The decline in breastfeeding occurred later than in America. It coincided with the new fashion for "demand feeding", and with a new movement to medicalize breastfeeding itself. A study of breastfeeding in different countries and over time indicates that the attitudes and advice of health professionals were significant factors in the success or otherwise of breastfeeding.

\section{Contrasting Medical Attitudes: The United States, Britain and New Zealand in the early Twentieth Century}

Many American doctors from the late nineteenth century doubted the superiority of breastfeeding over scientifically formulated milk products. Thomas Morgan Rotch, Professor of Diseases of Children at Harvard University in the 1890s, argued that although

(C) Linda Bryder 2005

* Associate Professor Linda Bryder, Department of History, University of Auckland, Private Bag 92019, Auckland, New Zealand.

I wish to thank the Wellcome Trust for the Short-term Travel Grant which enabled me to undertake the research for this paper.

${ }^{1}$ Rima D Apple, 'A century of infant feeding in the United States and New Zealand', in S Atkins, K Kirkby, P Thomas, J Pearn (eds), Outpost medicine: Australasian Studies on the History of Medicine, Third National Conference of the Australian Society of the History of Medicine, Hobart, 1993, University of Tasmania, 1994, pp. $303-10$, p. 304.

${ }^{2}$ Jacqueline H Wolf, Don't kill your baby: public health and the decline of breastfeeding in the nineteenth and twentieth centuries, Columbus, Ohio State University Press, 2001. See also Jacqueline H Wolf, 'Don't kill your baby': feeding infants in Chicago, 1903-1924', J. Hist. Med. Allied Sci., 1998, 53: 219-53. 


\section{Linda Bryder}

breast milk was the ideal food for infants, the conditions of modern life had made its supply and quality unreliable. ${ }^{3}$ These doctors increasingly viewed women, and especially "nervous" upper- and middle-class women, as physiologically incapable of producing the quantity and quality of breast milk required to rear a healthy infant, just as they were no longer able to give birth "naturally". ${ }^{4}$ Rotch maintained that the mammary gland "could easily be adversely affected by nervous debility or other physiological problems". 5 Emmett Holt, Professor of Diseases of Children at Columbia University College of Physicians and Surgeons 1901-22, claimed that three out of four "society" women in New York could not successfully suckle their babies, however much they might wish to do so. ${ }^{6}$

By the 1930s the American paediatrician Joseph Brennemann argued against breastfeeding for different reasons. He explained,

I remember vividly an infant of about fourteen months who had nursed an abundant breast for a year. Attempts to get him to take a bottle, or cup, or spoon food at that late period were unsuccessful. The mother now proceeded to starve him into it by withholding the breast. He refused all food and took practically no water. When I saw him in consultation several days later he was in a coma with a marked hyperpnea, would no longer take the now empty breast, and died a few hours later. ${ }^{7}$

Such a scenario, he said, could be avoided by getting the baby used to the bottle from the beginning.

By contrast to Brennemann's alarmist story about withholding the bottle, a few years later a British paediatrician Dr Harold Waller told a different story of a baby who was breastfed initially but, when breastfeeding failed, was put on the bottle. Its weight improved, but he explained,

when seven seeks old it caught a common "cold in the head." Within a few days it was dead. The hospital has certified it died of bronchitis with collapse of the lungs as a contributory cause. In fact, it died from its failure to get a flying start and that in turn was due to its mother's lack of sufficient breast-milk. Nothing is more striking than the high resistance to catarrhal infections of the successfully breast-fed. ${ }^{8}$

Statistical evidence was on the side of Waller. Mortality studies from the late nineteenth century showed the superiority of breastfeeding over bottle feeding, a widely known fact among those working in public health. ${ }^{9}$ For example, Liverpool's Medical Officer of Health calculated in the early twentieth century that the death rate from infant diarrhoea

\footnotetext{
${ }^{3}$ Richard A Meckel, Save the babies: American public health reform and the prevention of infant mortality 1850-1929, Baltimore, Johns Hopkins University Press, 1990, p. 57.

${ }^{4}$ See I Loudon, Death in childbirth: an international study of maternal care and maternal mortality 1800-1950, Oxford, Clarendon Press, 1992, pp. 352-7; J Leavitt, 'Joseph DeLee and the practice of preventive obstetrics', Am. J. Public Health, 1988, 78 (10): 1353-61, pp. 1353-9.

${ }^{5}$ Meckel, op. cit., note 3 above, p. 52.
}

\footnotetext{
${ }^{6}$ Cited by F Truby King, 'Physiological economy in the nutrition of infants', New Zealand Medical Journal (NZMJ) 1907, 6: 79.

${ }^{7} \mathrm{~J}$ Brennemann, 'Psychologic aspects of nutrition in childhood', J. Pediatr., Aug. 1932, 1 (2): p. 152; see also C Anderson Aldrich, 'Science and art in child nourishment', J. Pediatr., Oct. 1932, 1 (4): 418.

${ }^{8}$ Harold Waller, Clinical studies in lactation, London, William Heinemann, 1938, p. 4.

${ }^{9}$ See Deborah Dwork, War is good for babies and other young children: a history of the infant and child welfare movement in England 1898-1918, London, Tavistock Publications, 1987.
} 
for breastfed infants was 20 per thousand, while among those fed on cow's milk it was a staggering 440 per thousand. ${ }^{10}$ Thirty years later Dr James Spence, later Professor of Child Health at Newcastle-upon-Tyne, argued that a restoration of the habit of breastfeeding would help save the lives of 15,000 infants in Britain each year. ${ }^{11}$

American paediatricians were undoubtedly aware of these statistics, and many did advocate breastfeeding. Yet they also appeared to accept that modern science would triumph and overcome the problems associated with artificial feeding. In the 1930s the Professor of Pediatrics at Washington University School of Medicine, Williams McKim Marriott, wrote in his textbook on infant nutrition, "With the modern knowledge of nutrition, an infant ... nourished by a prepared formula can be as healthy in every respect as the breast-fed infant". He thought that breastfeeding should be encouraged among the "poor and ignorant" as it was "difficult for people of this class to carry out satisfactory artificial feeding". ${ }^{12}$ He told a 1932 symposium, "There is nothing mysterious and sacred about breast milk, it is just food. It is perfectly possible to prepare an artificial formula which meets all the nutritional requirements". ${ }^{13}$ Supplements were also advised. By the 1940s some American paediatricians recommended desiccated steak for babies one to three weeks old. ${ }^{14}$

By contrast to the United States, medical opinion in early-twentieth-century New Zealand was strongly supportive of breastfeeding. Writing on infant diarrhoea in 1907, one sanitary inspector claimed that, "the most grave responsibility rests on the mothers who, from carelessness, ignorance, or selfishness, do not feed their children at the breast". He thought that the absence of breastfeeding was "understandable (though maybe not justifiable)" in the manufacturing districts in England, where many women worked in factories, but that the neglect was "less excusable" in New Zealand where few mothers were wage-earners. ${ }^{15}$ New Zealand's Assistant Chief Health Officer, Dr Joseph Frengley, claimed in 1912 that it was the "so-called upper classes, Society women ... Social parasites" who did not breastfeed. In his view, "the working women, the true mothers, the women with the breasts", had no trouble. He was satisfied that it was a mistake "from the natural point of view" to keep alive babies who could not be breastfed by their mothers; he said, "If we only bred from the mothers who can suckle their babies we should soon have proper motherhood". ${ }^{16}$ Yet another doctor claimed in 1908 that, "Any woman who could nurse her child, and would not, took the risk of being morally guilty of homicide by omission". 17

\footnotetext{
${ }^{10}$ Cited in New Zealand Department of Health, Annual Report 1907, Appendices of the Journal of the House of Representatives (AJHR), 1907, H-31, p. viii.

${ }^{11} \mathrm{~J}$ C Spence, 'Encouragement of breast feeding', Mother and Child, 10, 5, Aug. 1939, 1 (4): 169-72, p. 170.

${ }^{12}$ Williams McKim Marriott, Infant nutrition: $a$ textbook of infant feeding for students and practitioners of medicine, London, Henry Kimpton, 1930, p. 93.

${ }^{13}$ Cited by E Pritchard, 'Changes in fashion in infant feeding', Mother and Child, Aug. 1932, 3 (5): 193.
}

\footnotetext{
14 'Commentary: infant feeding', Mother and Child, Jan. 1959, 29 (10): 237-8, p. 237.

${ }^{15} A J H R, \mathrm{H}-31,1907$, p. 39, cited in L Bryder, A voice for mothers: the Plunket Society and infant welfare 1907-2000, Auckland University Press, 2003, p. 6.

${ }^{16}$ Truby King's notebook, Plunket Society Archives (PSA), 89-098-29, Hocken Library, Dunedin, cited in Bryder, op. cit., note 15 above, p. 6.

${ }^{17}$ New Zealand Herald, 3 Feb. 1908, cited in Bryder, op. cit., note 15 above, p. 6; "nursing" and "suckling" were euphemisms for breastfeeding.
} 


\section{Linda Bryder}

Firmly committed to supporting breastfeeding, New Zealand doctors also had some influence on Britain. With the lowest infant death rate in the world, New Zealand was looked to as a model for infant welfare. ${ }^{18}$ In particular it became famous for the work of the Society for the Health of Women and Children, founded by Dr Frederic Truby King and commonly known as the Plunket Society. King was invited to set up a similar scheme in Britain at the end of the First World War - the Mothercraft Training Society, founded in 1918. A major aim of both organizations was the promotion of breastfeeding. While Truby King worked on creating a safe alternative to breast milk ("humanized milk" or cow's milk modified to resemble human milk as closely as possible), he was unequivocal in his advocacy of breastfeeding. At his death in 1938, the British journal Mother and Child, the official mouthpiece of the National Council for Maternity and Child Welfare and its constituent societies, claimed that Truby King had "hypnotise[d] thousands of mothers into the belief that breast feeding [was] the important factor in infant care". ${ }^{19}$ So-called "typical admissions" at his Mothercraft Training Society in London in 1918 included "Baby Harbor". This was, we are told, the story of "Establishment of full breast feeding in a woman of 40 who had not nursed any of her previous seven babies." Her husband, a carter in Vauxhall, apparently expressed his appreciation of his wife's achievement by saying admiringly — "My word, mother, you're a real mother this time and no mistake!",20 The clear message for women, from the Mothercraft Training Society in Britain and the Plunket Society in New Zealand, was that breastfeeding made them better mothers. Five years after its founding in 1907, the Plunket Society claimed some success in promoting breastfeeding. It noted approvingly that women who could not breastfeed "become more and more apologetic", while others who could not breastfeed in the past could now do so with proper advice and encouragement, so that "they are no longer subject to the humiliation of feeling themselves to be only "half mothers'". It claimed that only five years previously "a large proportion" of young mothers did not even contemplate breastfeeding; now bottle-feeding was coming to be regarded as "bad form". ${ }^{21}$ By the 1930s breastfeeding was virtually universal in New Zealand, with 91 per cent of women breastfeeding when first seen by the infant welfare ("Plunket") nurse, who visited over 80 per cent of newborn babies. ${ }^{22}$

In Britain, it was not only those associated with the Mothercraft Training Society who supported breastfeeding. Dr George McCleary stressed that his "milk depot", set up in Battersea, London, in 1903 and a model for others including New Zealand, was not merely a station for dispensing clean and cheap milk; mothers had to give good reasons for abandoning breastfeeding. ${ }^{23}$ Dr Eric Pritchard, who established an infant welfare

\footnotetext{
${ }^{18}$ See, for example, Andrew Balfour and H H Scott, Health problems of the empire: past, present and future, London, W Collins, 1924, p. 182. These New Zealand statistics did not include Maori infant mortality.

${ }^{19}$ Editorial, Mother and Child, March 1938, 8 (12): 453-4, p. 454.

${ }^{20}$ Mothercraft Training Society Report for $1918-19$, p. 18 (italics and underlining in original).

${ }^{21}$ Plunket Society, Annual Report, 1912-13, p. 11. Wet nursing had never been a viable alternative
}

for middle-class women in New Zealand. Just as there
was a perennial shortage of domestic servants, so there
was a dearth of women for this occupation; neither
attracted Maori women. See also Sue Kedgley, Mum's
the word: the untold story of motherhood in New
Zealand, Auckland, Random House, 1996, p. 11 .
${ }^{22}$ Helen Deem and Murray McGeorge, 'Breast
feeding', NZMJ, 1958, 57: 539-56.
${ }^{23}$ G F McCleary, The early history of the
infant welfare movement, London, H K Lewis,
1933, p. 80 . 


\section{Breastfeeding and Health Professionals, 1900-1970}

centre at St Marylebone, London, in 1905 and became a figurehead in the infant welfare movement in Britain, argued that his centre differed from "milk depots" like Battersea because it emphasized advice to keep the infants on the breast rather than encouraging artificial feeding by the supply of modified milk. ${ }^{24}$ Pritchard even suggested introducing a bonus for mothers who successfully breastfed for nine months. ${ }^{25}$ Dr Mary Scharlieb, well known for her infant welfare work in Whitechapel, London, said in 1918 that she "honestly agree[ed] with Dr Truby King that the greatest factor of all is the want of breast feeding". She reached this conclusion by comparing the health of the local Jewish community with the non-Jewish; the former mostly breastfed their babies. ${ }^{26}$

The American trends in infant feeding appeared to be quite different from those in Britain and New Zealand, something which frequently struck visitors to North America. In 1932 Pritchard noted the American tendency to "cultivate less and less the habit of natural feeding", a trend which he did not see occurring in Britain. ${ }^{27}$ Canada too followed the American pattern. A New Zealand nurse who set up a Mothercraft Training Society in Canada claimed in 1933 that there was "a much more normal outlook on Maternity in New Zealand, with the result that 87 per cent of the babies born here, as against 30 per cent in Canada, were naturally fed". ${ }^{28}$ The medical adviser to the Plunket Society, Dr Helen Deem, commented in the 1940s that in America breastfeeding had been the exception for many years. ${ }^{29}$ Another visitor to the United States in the 1940 s, the British natural childbirth advocate Helen Heardman, noted the "exceedingly low" percentage of mothers embarking on breastfeeding: "There seems to be a tradition against attempting", she said. ${ }^{30}$

\section{Infant Formula Advertisements in Britain}

In America Rima Apple found an alliance between doctors and infant feeding manufacturers who promoted their products as more scientific than breast milk. She explained that medical societies sought to limit the dissemination of information about commercial foods to medical personnel only, and that by the 1930s they had generally succeeded. ${ }^{31}$ This did not happen in Britain where advertisements appeared for example in Mother and Child, which reached a non-medical audience. British infant feeding companies appealed directly to mothers and nurses, probably because doctors in theory at least promoted breastfeeding. It is very clear from an analysis of these advertisements that manufacturers found the breast a formidable foe. A direct comparison with breast milk was the constant target. Milk formula companies did not claim superiority over the breast. Well aware that doctors claimed breastmilk was the best food for infants, they argued that their products were just as good.

\footnotetext{
24 'Pritchard's memoirs', Mother and Child, April 1945, 16 (1): 11.

${ }^{25}$ E Pritchard, 'The case of breast-feeding', Mother and Child, Sept. 1941, 12 (6): 127-8, p. 127.

${ }^{26}$ Mothercraft Training Society (Babies of the Empire), Report of public meeting at the Mansion House, 17 December 1918, p. 27, Highgate Literary and Scientific Institution, London.
}

\footnotetext{
${ }^{27}$ E Pritchard, 'Changes in fashion in infant feeding', Mother and Child, Aug. 1932, 3 (5): 193.

${ }^{28}$ Plunket Society, Auckland Branch, 25th Annual Report, 1933.

${ }^{29}$ Plunket Society, Report of Twenty-ninth General Conference, 1948, p. 15.

${ }^{30}$ Mothercraft Training Society Magazine, Autumn 1948 , p. 680.

${ }^{31}$ Apple, op. cit., note 1 above, p. 306.
} 


\section{Linda Bryder}

"Lactogen" advertisements, including pictures of beautiful thriving babies, explained that its curd was "very similar to that of breast milk" so that it was suitable for "even the most delicate infant". ${ }^{32}$ Another revealed that Lactogen had a carbohydrate content as in breast milk, and had been prepared to "bring it up to normal breast milk standard". 33 Readers were assured of a product "closely akin to the characteristics of natural milk". A sequel to this advertisement asked, "Why Lactogen so adequately replaces Breast Milk where natural Feeding is deficient or impossible". It explained, "Scientifically and in actual practice, Lactogen resembles Baby's natural food as closely as is possible. Both the proportions of its food elements and its physiological character are practically identical". 34 This was also demonstrated "scientifically" by pictures of fat globules showing maternal milk and Lactogen to be the same. This was also a line taken by Cow \& Gate Milk Food.

Ostermilk apparently had "reached a complete agreement ... with breast milk". The baby could take them alternately without the least disturbance. The same applied to Cow \& Gate: "There is no reason why a baby should be weaned in cases where breast feeding does not become fully established until some weeks after birth since any deficiency can be made up with a complementary feed of COW \& GATE afterwards. Cow \& Gate Milk Food is ideal in this respect. It is easily prepared, is sterile, and the protein of the dried milk is a close approximation to that of the mother's milk." 35

There were others, such as Allenburys' Food for Infants, which "closely resemble[d] the natural milk". ${ }^{36}$ Elsewhere readers were told, "the logical alternative to breast milk is Humanised Trufood nearest to mother's milk". ${ }^{37}$ Karo came on the market in 1937, with recommendations from America's Professor Marriott, and under the heading, 'An almost exact reproduction of mothers' milk/ Remarkable clinical results/ Interesting case-histories from over 900 doctors and nurses' ${ }^{38}$ No details were provided on the nature of the clinical trials.

These advertisements from the 1930s contrasted markedly with later ones which made no mention of breast milk. By the 1950s when the popularity of breastfeeding was declining, commercial companies no longer felt the need to compete with the breast. In the 1930s, however, they were clearly competing with a medical view of the superiority of breast over bottle feeding. An analysis of their strategies showed how entrenched those medical views were.

\section{The Effects of Hospitalization of Childbirth and "Routines" on Breastfeeding}

Jacqueline Wolf argues that hospitalization of childbirth had a "devastating" effect on successful breastfeeding, as newborn babies were hustled off to nurseries. ${ }^{39}$ In particular,

\footnotetext{
${ }^{32}$ Mother and Child, Nov. 1932, 3 (8):

335. Emphasis added.

${ }^{33}$ Mother and Child, Feb. 1933, 3 (11):

413. Emphasis added.

${ }^{34}$ Mother and Child, April 1938, 9 (1): 31.

${ }^{35}$ Mother and Child, April 1935, 6 (1): 29. Emphasis added.
}

\footnotetext{
${ }^{36}$ Mother and Child, April 1933, 4 (1): 27.

${ }^{37}$ Mother and Child, Dec. 1933, 4 (9): 371. Emphasis added.

${ }^{38}$ Mother and Child, Oct. 1937, 8 (7): 295.

${ }^{39}$ Wolf, 'Don't kill your baby', p. 250; Wolf, Don't kill your baby, p. 193, both cited in note 2 above.
} 
she claims the routine feeding advocated by doctors and practised in hospitals led "inexorably" to failure of breast milk supply.

Hospitalization of childbirth occurred rapidly in America in the twentieth century, as doctors persuaded women that hospital was the safest place in which to give birth. ${ }^{40}$ It occurred just as rapidly in New Zealand. Even before the Social Security Act of 1938 provided free hospital deliveries, 78 per cent of European New Zealand women were having their babies in hospital. ${ }^{41}$ Whether these institutions were small private nursing homes or larger public hospitals, they were run in the same way-they included nurseries, and practised routines in infant feeding and management. Yet these systems did not lead to a decline in breastfeeding in the 1920s and 1930s in New Zealand. As noted earlier, 91.5 per cent of mothers were breastfeeding when first seen by the Plunket nurse in the late $1930 \mathrm{~s}^{42}$ In Britain too, despite babies being hustled into nurseries in hospitals in the 1930s, it was estimated in 1933 that 87 per cent left hospital fully breastfed. ${ }^{43}$ The pattern of women breastfeeding when they left hospital after one or two weeks and then stopping in the following week was often commented on. ${ }^{44}$

As one nurse who visited Britain in 1960 explained, "[In New Zealand] all the mothers have their babies in Maternity Homes and all try to breast feed them. This is taken for granted ... Even if we were short staffed we still supervise at feed times, which gives confidence to the Mothers". ${ }^{45}$ The same year, Ronald Illingworth, Professor of Child Health at Sheffield University, related the response of a woman bottle-feeding her baby in an American hospital when asked by a British visitor why she was not breastfeeding. She replied that it had never struck her to do so. ${ }^{46}$

Wolf argues that hospitalization undermined breastfeeding primarily because the hospital routines broke the fundamental law that the more the baby sucked the more the breast produced. ${ }^{47}$ Yet hospital staff in Britain and New Zealand were well aware of the need to empty breasts completely to replenish the supply. In his 1936 guidelines to midwives, the British Professor of Paediatrics Alan Moncrieff stressed the importance of the breasts always being emptied; this would also prevent engorgement. He advised against providing complementary feeds, "as one of the essential factors in establishing a good flow of milk is an actively-sucking hungry baby". ${ }^{48}$ Geoffrey Fleming, Professor of Child Health, Glasgow University, similarly noted in his 1938 textbook on infant feeding that breastfeeding had a stimulating effect on the breast and that "At each milking the breasts should be emptied as completely as possible, for unless this is done the supply is apt

\footnotetext{
${ }^{40}$ Irvine Loudon, 'Childbirth', in Irvine Loudon (ed.), Western medicine: an illustrated history, Oxford University Press, 1997, p. 217.

${ }^{41}$ Philippa Mein Smith, Maternity in dispute: New Zealand 1920-1939, Wellington, NZ, Historical Publications Branch, Department of Internal Affairs, 1986. The hospitalization of Maori women in childbirth occurred slightly later and related to Maori urbanization, at 17 per cent in 1938 and 90 per cent by 1960; ibid., p. 64.

${ }^{42}$ Deem, op. cit., note 22 above, pp. 539-56.

${ }^{43} \mathrm{~J}$ C Spence, 'Encouragement of breast feeding', Mother and Child, Aug. 1939, 10 (5): 269-70, p. 170.
}

\footnotetext{
${ }^{44}$ See, for example, Pritchard, op. cit., note 25 above, pp. 127, 137; Mothercraft Training Society Magazine, spring 1939, p. 256.

${ }^{45}$ Marie J Scott, 'Thoughts on work in Great Britain', Mothercraft Training Society Nurses League Magazine, summer 1960, pp. 30-1.

${ }^{46} \mathrm{R}$ S Illingworth, 'Breast feeding versus bottle feeding', Mother and Child, 1960, 31 (3): 71-3, p. 71.

${ }^{47}$ Wolf, 'Don't kill your baby', op. cit., note 2 above, p. 240.

${ }^{48}$ Alan Moncrieff, The management of the newborn baby: a guide for midwives, London, Association of Maternity and Child Welfare Centres, 1936, pp. 18, $19,23$.
} 


\section{Linda Bryder}

to fail" ${ }^{49}$ In New Zealand, Helen Deem told a Plunket nurse in 1954, "It is inefficient emptying of the breast which is so often responsible for the cessation of the supply". 50 Midwives in training had all been subjected to Truby King's infant care manual, The expectant mother and baby's first month, in which he stated, "Failure to breast-feed is often due to the Nurse not putting baby to the breast soon enough after birth, and not persevering long enough". 51

While supporters of feeding babies on demand in the post-Second World War period argued that routine feeding had been responsible for undermining breastfeeding, many women had in fact succeeded in breastfeeding up to nine months following a regular regime. One Auckland mother who had done so, commented in 1952, "If babies were fed at any old time mother would never have a free moment". Another claimed, "Nature also intends a mother to get a little rest and sleep, which is impossible if a baby has to be fed every few minutes". 52 In Britain the Mothercraft Training Society reported a recent admission to its hospital section, "Elizabeth House": "This mother had practised "demand feeding' and had given twelve feeds in 24 hours to the utter exhaustion of herself and the baby, which has one thinking there is something to be said for regular feeding after all!" 53 One mother explained, "We used to tide our babies over till the feed was due by drinks of water and a cuddle; they very soon were gently trained to wake at the arranged times. Therefore we and our babies were happy in a secure routine; we both knew where we were, and liked it." 54

The British breastfeeding advocate Dr Harold Waller found at his London clinic that demand-fed babies sometimes lost weight, but when put on a more regular feeding schedule they improved. He commented that he did not know why, except that the babies appeared more settled on fewer feeds which enabled them to sleep longer and this reacted beneficially on the mother and her milk supply. ${ }^{55} \mathrm{He}$ would probably have agreed with Plunket's medical adviser, Helen Deem, who advocated "flexible regularity", enabling a mother to plan her day and therefore be more relaxed about breastfeeding. ${ }^{56}$ Setting aside some time for breastfeeding also meant, Waller wrote, that the baby's claims would be kept in mind. ${ }^{57}$ The decline in breastfeeding in New Zealand did not occur during the era in which routine feeding was more widely practised, but rather once demand feeding had become the fashion, as will be discussed.

The attitudes of the medical and nursing staff in hospitals appear to have been an important factor in establishing successful breastfeeding. As part of a wider study on breastfeeding in 1953, Helen Deem wrote to thirty-three nurses in areas with above average breastfeeding rates. Their replies indicated that with supportive staff at the local maternity hospital and a supportive Plunket nurse, the chances of successful breastfeeding were high. A nurse from one Auckland suburb wrote that they had two very co-operative nursing

${ }^{49} \mathrm{G}$ B Fleming, Notes on infant feeding, 2nd ed. revised, Glasgow, John Smith \& Son, 1938, p. 10.

${ }^{50} \mathrm{H}$ Deem to M Neumann, 15 Feb. 1954, PSA, 576.

${ }^{51} \mathrm{~F}$ Truby King, The expectant mother and baby's first month, 4th ed., Wellington, Government Printer, 1935 , p. 79.

${ }^{52}$ Auckland Star, 1 Oct. 1952.

\footnotetext{
${ }^{53}$ Mothercraft Training Society Magazine, spring 1950, p. 839.

${ }^{54}$ Mothercraft Training Society Magazine, summer 1958, letters, pp. 9-16.

${ }_{55}$ Waller, op. cit., note 8 above, p. 22.

${ }^{56}$ Plunket Society, Report of Twenty-ninth General Conference, 1948, p. 16.

${ }^{57}$ Waller, op. cit., note 8 above, p. 40.
} 


\section{Breastfeeding and Health Professionals, 1900-1970}

homes which "do all they can to establish breast feeding". ${ }^{58}$ Another replied that the local hospitals gave the mothers "a good training ... Our Doctors are keen on Breastfeeding. We ourselves are keen". ${ }^{59}$ The nurse from Matamata, a small town in the centre of North Island, replied, "the local hospital is an excellent one and as all the doctors and Sister Ferguson, the Matron, are very keen on breastfeeding, the number of babies fully breastfed on discharge is very high ( 82 per cent)". ${ }^{60}$ The nurse from another small town reported upon a co-operative staff at the local hospital where she spent one and a half hours one morning a week. She sometimes persuaded women to breastfeed who had not planned to do so. ${ }^{61}$ Enthusiasm for breastfeeding shone through the letters: "I myself am very keen on babies being breastfed for as long as possible so perhaps my enthusiasm may be infectious and have some effect on the mothers. I always endeavour to visit the mothers as soon as possible after they leave hospital, because I think that is the usual time when they wean off their own bat, or grandma's advice". 62 "Also I think that being able to meet the mothers in Hospital makes a big difference. I find that the mothers I have met and talked to in Hospital usually ring me for advice if they are worried about the baby before my first visit ... Why they keep on breastfeeding longer than others I just don't know, but I'm sure most of them wouldn't without supervision". 63 Another replied, "Above all I think a calm confident approach that they can breastfeed successfully without too much fuss goes a long way with them". ${ }^{64}$ Such individual support from an infant welfare nurse who visited mothers at home for the first three months of the baby's life was a particular feature of New Zealand's Plunket system, which at least one mother who emigrated to America after the war missed. ${ }^{65}$

In Britain the Royal College of Midwives' response in 1949 to a lukewarm article on breastfeeding in the journal Mother and Child was indicative of the strength of its support for this form of infant feeding. The College executive condemned the article, pointing out that, "artificial feeding cannot equal the natural, either physically or psychologically for the baby or the mother. It is considered that the sentiments expressed are unworthy of a journal which claims to be that of the National Baby Welfare Council". ${ }^{66}$ The President of the College from 1949 to 1952 was Mabel Liddiard who had been matron of the Mothercraft Training Centre from 1920, Nursing Director to the Mothercraft Training Society, 1936-1945, and was herself a keen advocate of breastfeeding. In the 1960s it was suggested that sometimes women in Britain were pressured into breastfeeding by their midwives. ${ }^{67}$ Similarly one New Zealand mother claimed that her Plunket nurse placed an "over

\footnotetext{
${ }^{58}$ A G Strayer to H Deem, 13 July 1953, PSA 576.

${ }^{59}$ O K Orris to H Deem, 17 July 1953, PSA 576.

${ }^{60}$ Gwen Johnson to H Deem, 22 July 1953,

PSA 576.

${ }^{61}$ Gwen Evans to H Deem, 23 July 1953, PSA 576.

${ }^{62}$ Plunket nurse to H Deem, 13 July 1953, PSA 576.

${ }^{63}$ Kathleen Lee to H Deem, 31 July 1953, PSA 576.

Telephones were fairly widespread in $1950 \mathrm{~s}$

New Zealand.

${ }^{64}$ Doris L Williams to H Deem, 20 July 1953, PSA 576; in 1937 one Plunket nurse had suggested that a bonus be given to all mothers who
}

breastfed: Evidence to Committee of Inquiry into Maternity Services, 1937, Nurse Arnott,

11 Aug. 1937, MS 78, Library Archives, Auckland Museum.

${ }^{65}$ The Weekly News, 6 Feb. 1946.

${ }^{66}$ Mrs F R Mitchell, General Secretary, Royal College of Midwives, letter to the editor, Mother and Child, April 1949, 20 (1): 22.

${ }^{67}$ Professor Gavin C Arneil, Department of Child Health, University Glasgow, 'Results of a dietary survey of Scottish children in relation to the return of infantile rickets', Mother and Child, Aug. 1968: 9-12, p. 9 . 


\section{Linda Bryder}

emphasis" on breastfeeding_- "even when she was ill and wanted to wean baby she was not allowed" she said. ${ }^{68}$

\section{Post-Second World War Professional Attitudes to Breastfeeding Diverge}

Dr Helen Deem carried out three surveys of the extent and duration of breastfeeding in New Zealand, in 1939, 1945, and 1952 (involving 9,000, 7,700 and 12,000 babies respectively). ${ }^{69}$ She found a drop in the percentage of mothers breastfeeding when first seen by the Plunket nurse, from 91.5 in 1939 to 74.4 per cent in 1952. The studies confirmed the general impression that breastfeeding was on the decline in the post-war years, a trend New Zealand shared with Britain. Duration of breastfeeding was also declining. In 1939, over 80 per cent of babies were breastfed for the first three months, and over 60 per cent for six months. ${ }^{70}$ A decade later only 21 per cent were breastfeeding for more than six months. ${ }^{71}$ In the 1950s the Plunket Society continued to advocate breastfeeding for six to nine months, though it was noted that breastfeeding for nine months was exceptional. ${ }^{72}$

While midwives and Plunket nurses continued to promote breastfeeding, some doctors in New Zealand were apparently becoming less convinced about the benefits of breastfeeding. Dr Montgomery Spencer, a highly respected paediatrician who had undertaken postgraduate paediatric training at Harvard University, described breastfeeding in 1938 as a "fetish". 73 A 1941 infant feeding study referred to a doctor who advised all his patients to discontinue breastfeeding after three months. The writer added, "When the Plunket Nurse was asked by these mothers if she agreed with this advice she had to use the utmost tact to put forward the ideas of her Society without causing any offence to the medical profession", ${ }^{74}$ something she probably did not achieve. When one woman consulted her doctor about mastitis following her return from hospital in 1954, she was told to "stop all this silly nonsense and wean the baby". He advised her: "Tie yourself up tightly—don't drink any liquids just wash your mouth out if it gets dry-take a double of doses of Epsom salts and that should fix it". He also told the nurse present, "Your mob are as helpful as a useless flea". ${ }^{75}$ When the nurse retorted that she would "take the matter up", the local Plunket Sister-in-Charge commented, "we feel that her enthusiasm for maintaining breast feeding had rather affected her correct attitude towards the medical profession" ${ }^{76}$ In 1963, another study of mothers' responses to Plunket nurses' advice recorded that in three cases the advice of the Plunket nurse had been "in direct contradiction to that given by the family doctor". In two cases, the difference had concerned breastfeeding problems. ${ }^{77}$

\footnotetext{
${ }^{68} \mathrm{~J}$ Y Yee, 'To help the mothers and save the babies', Public Health thesis, University of Otago, 1962 , p. 21.

${ }^{69}$ Dominion, 21 Nov. 1952; the results were published after Deem's death, NZMJ, 1958, 57: 539-56.

${ }^{70}$ Plunket Society, Wellington Branch minutes, 18 Aug. 1938.

${ }^{71}$ Plunket Society, Report of Twenty-ninth General Conference, 1948, p. 15.

${ }^{72}$ Margaret Woods, 'Plunket nursing in the Invercargill area', Public Health thesis, University of Otago, 1951, p. 30.
}

\footnotetext{
${ }^{73}$ Dominion, 22 June 1938.

${ }^{74}$ M I Elliott, M I and M D Rohan, 'Infant feeding', Public Health thesis, University of Otago, 1941, p. 25.

${ }^{75} \mathrm{H}$ McMullen to A W S Thompson, 3 July 1954 , PSA 580.

${ }^{76} \mathrm{M}$ I Nicholls to A W S Thompson, 7 July 1954, PSA 580.

${ }^{77}$ K V Marriott, 'The Plunket Society: some opinions', Public Health thesis, University of Otago, 1963, p. 11.
} 


\section{Breastfeeding and Health Professionals, 1900-1970}

In the post-war period, mothers in New Zealand had more contact with their doctors than previously. During the first half of the twentieth century the Plunket Society had a virtual monopoly on infant health care in New Zealand. Plunket nurses supervised the health of most infants and until 1939 also conducted ante-natal checkups of mothers. At the same time there was an emerging group of doctors specializing in infant health; they found themselves competing with the nurses of the Plunket Society. For example, Dr Montgomery Spencer complained to the Plunket Society Council in 1937 that it was "not at all uncommon for mothers to be told by Plunket nurses that my methods of feeding will prove harmful to their babies" ${ }^{78}$ His concern showed the considerable influence Plunket nurses had at the time. Following the 1938 Social Security Act, mothers had more contact with doctors, who now provided free ante-natal checkups, free hospital deliveries, free postnatal checkups and subsidised general practitioner services.

Part of the reason for doctors' flagging support for breastfeeding in the 1950s possibly related to a new strain of penicillin-resistant staphylococcal aureus which was invading maternity hospitals, both in Britain and New Zealand. The British paediatrician John Forfar believed this epidemic was responsible for increased levels of artificial feeding in Britain. The bacterium commonly caused boils and carbuncles, but in breastfeeding women it could cause a breast abscess, which was "a painful and disturbing event ... often requiring hospital readmission and surgical intervention". Forfar explained how fear and apprehension of such an occurrence on the part of the mother, allied to concern by the obstetrician, led many mothers to opt for bottle feeding and many obstetricians to advise against breastfeeding. As a result, despite attempts by those who believed in the importance of breastfeeding to pressure and cajole mothers to adopt it, feeding "which had been in the order of $80-90$ per cent in the pre-War era [in Britain] fell to around 10 per cent in many areas". 79 This epidemic also reached New Zealand maternity hospitals from 1955, and was known locally as the H-Bug, resonating with the H-bomb, so much in the news at the time.

Lack of enthusiasm among the medical profession for breastfeeding in the post-war period might also have been related to its association with a new lay movement promoting natural childbirth. In New Zealand, the Natural Childbirth Association was set up in 1951, in response to a perceived growing medicalization of childbirth. The Parents' Centre, as the association was called from 1952, advocated "humanizing" childbirth, with less medical intervention and pain relief, rooming-in in hospitals, demand feeding and breastfeeding. The British equivalent, the National Childbirth Trust, was set up in 1957. Many doctors distrusted and opposed this new movement. Dr Thomas Corkill, a senior obstetrician in New Zealand, dismissed the members of the Parents' Centre as "a bunch of Communists", ${ }^{80}$ while Flora Cameron, the New Zealand Health Department's Director of Nursing, described them disparagingly as "the jump for joy people". ${ }^{81}$

\footnotetext{
${ }^{78} \mathrm{M}$ Spencer to Plunket Society President and Council, 18 Dec.1937, PSA 239.

${ }^{79}$ John Forfar, 'Changing paediatric perceptions and perspectives', in John O Forfar (ed.), Child health in a changing society, Oxford University Press, 1988 , p. 272.
} 


\section{Linda Bryder}

The movement was influenced by the British doctor, Grantly Dick Read, who wrote a book on natural childbirth in 1942 , which went into many editions. ${ }^{82}$ Natural childbirth was promoted as part of the bonding process between mother and child, for the child's psychological health, and breastfeeding was part of the package. Dick Read was a strong supporter of breastfeeding. In 1950 he wrote to a friend, "I cannot think how the [medical] profession, even though only 10 per cent of its members are relatively intelligent, can allow the scandalous suppression of breast feeding. It is the most myopic idiocy". ${ }^{83}$ Dick Read's main New Zealand contact was Dr Maurice Bevan-Brown, who had worked at London's Tavistock Clinic in the 1930s where Dick Read was subsequently based. Read wrote the preface to Bevan-Brown's Sources of love and fear, in 1950. Like Dick Read's works, this book sold well and was soon out of print. ${ }^{84}$ In it Bevan-Brown pointed out that breastfeeding (or the deprivation thereof) was of long-term psychological importance. He cited Sigmund Freud who had written that, "No one who has seen a baby sinking back satiated from the breast and falling asleep with flushed cheeks and a blissful smile can escape the reflection that this picture persists as a prototype of sexual satisfaction in later life". ${ }^{85}$ Bevan-Brown too saw a "close similarity between breast-feeding and adult coitus", and of "orgasm in both cases". For girls, he believed there was a connection between oral deprivation in the first year and vaginal frigidity twenty or more years later. He confidently claimed that if the female baby was adequately breastfed and thus achieved "a complete and satisfactory sensuous relationship with her mother", she would not be frigid as a wife, provided she did not marry a man she disliked. Breastfeeding was not in itself enough, it was the experience of the breastfeeding that was important_- "unless this breast-feeding process is a true human copulation, that is to say, unless it is a mutual reciprocal and personal act as well as a mechanical process, the baby may not thrive". He explained that Freud used the word "sexual" to describe feelings experienced by mother and infant in this "copulative breast-feeding process". 86

Nor was Bevan-Brown alone in this belief; a doctor at London's Institute of Psychoanalysis argued in 1935, "The mother derives normally a more or less open sexual pleasure from suckling and transmits this to the baby through her nipple. I believe that it will affect the baby's pleasure and may even interfere with his feeding if the mother is unable to enjoy feeding or tries to suppress the sexual feelings accompanying suckling." She believed it wrong to prevent the baby biting the nipple "or other forms of aggression". The baby was to be allowed to play with the nipple and not be hurried. The baby's failure to take

\footnotetext{
${ }^{82}$ Grantly Dick Read, Revelation of childbirth: the principles and practice of natural childbirth, London, W Heinemann, Medical Books, 1942, reprinted annually until 1953, latterly as Childbirth without fear. Dick Read officially hyphenated his name in 1958. See also Mary Thomas (ed.), Post-war mothers: childbirth letters to Grantly Dick-Read, 1946-1956, University of Rochester Press, 1997.

${ }^{83}$ Dick Read to Mrs Gayle Aiken, 14 June 1950, PP/ GDR/D.268, Wellcome Library, Manuscripts and Archives.
}

\footnotetext{
${ }^{84}$ Kedgley, op. cit., note 21 above, p. 177.

${ }^{85}$ Sigmund Freud, The standard edition of the complete psychological works of Sigmund Freud. Vol. VII: Three essays on the theory of sexuality (1901-1905), transl. J Strachey, London, Hogarth Press, 1953, p. 182.

${ }^{86}$ Maurice Bevan-Brown, The sources of love and fear, with contributions by members of the Christchurch Psychological Society, Wellington, Reed, 1950, pp. 18, 20, 24, 27.
} 
to breastfeeding was also a serious matter. It "may occur because the baby has a constitutionally under-developed capacity for enjoying oral pleasures, which is often linked up with an early repression of the sexual and aggressive instincts". 87

This new child psychology enjoyed close links with the natural childbirth movement; part of the motivation for drug-free childbirth was the immediate intimate relationship between mother and child that it promoted. Yet, the natural childbirth movement was regarded with great suspicion by some members of the medical profession and some women shared that suspicion. Moreover, the major childrearing manual consulted by women in the 1950s was written by the American paediatrician, Dr Benjamin Spock, who did not share Dick Read's passion for breastfeeding. Dick Read carried out what he described as a very "acrimonious" correspondence with Spock about his failure to support breastfeeding. ${ }^{88}$ He pointed out that Spock devoted only four pages to breastfeeding in his manual, with twenty-four pages given to artificial feeding. A reviewer of Spock's book in Mother and Child commented that he wrote convincingly on the importance of breastfeeding, yet "not too dogmatically so that the mother who is unable to do so will not have too great a sense of failure or guilt". ${ }^{89}$ The new permissive child-centred parenting of the 1950s did not necessarily include breastfeeding. Note, for example, Charles Anderson Aldrich, who published a landmark book in American childcare literature entitled Babies are human beings, which promoted a more relaxed approach to child rearing. ${ }^{90} \mathrm{He}$ advised, "Every breastfed baby should be educated into the technic [sic] of bottle feeding from birth because such treatment prevents weaning difficulties."91

Spock and his colleagues did however promote a more permissive child-centred approach to childrearing, which eschewed routines in favour of demand feeding. Demand feeding at the breast, however, could be very taxing. One study in Britain in 1958 found only two out of 106 mothers succeeding; they both lived with their mothers, had practically no domestic responsibilities and received considerable help with the baby. The commentary noted in italics, "Indeed their only occupation was breast feeding". 92 Demand breastfeeding, unless the mother had considerable support, was for many not a viable option, particularly if there were other children to look after. Demand feeding with a bottle, however, was easier-the bottle could be given by someone else, including the husband. Husbands were to play a bigger role in childcare in the new child psychology of the postwar era, and bottle-feeding gave them this opportunity. As Katherine Arnup noted of postwar Canada, child guidance authors promoted the notion that bottle-feeding had the added advantage of enabling the new father to assume responsibility for feeding the baby. ${ }^{93}$

\footnotetext{
${ }^{87}$ Melitta Schmideberg, 'The psychological care of the baby', Mother and Child, November 1935, 6 (8): 304-8, p. 306.

${ }^{88}$ Dick Read to Charlotte and Gayle Aiken, USA, 1948, PP/GDR/D265; Dick Read to Charlotte Aiken, 14 Sept. 1951, PP/GDR/D269, Wellcome Library, Manuscripts and Archives.

${ }^{89}$ Book review of B Spock, The pocket book of baby and child care, in Mother and Child, Nov. 1956, 27 (8): 192.

${ }^{90} \mathrm{C}$ Anderson Aldrich and Mary M Aldrich, Babies are human beings, New York, Macmillan, 1938, republished in Britain as Understanding your baby,
}

London, Black, 1939, cited in Cathy Urwin and Elaine Sharland, 'From bodies to minds in childcare literature', in Roger Cooter (ed.), In the name of the child: health and welfare 1880-1940, London, Routledge, 1992, pp. 187-8.

${ }^{91} \mathrm{C}$ Anderson Aldrich, 'Science and art in child nourishment', J. Pediatr., Oct. 1932, 1 (4): 418.

${ }^{92}$ Mothercraft Training Society Nurses League Magazine, summer 1958, p. 19, reprinted from Nursing Times, 21 March 1958.

${ }^{93}$ Katherine Arnup, Education for motherhood: advice for mothers in twentieth century Canada, University of Toronto Press, 1994, p. 99. 


\section{Linda Bryder}

Plunket guide books continued to diverge however; in the 1950s they stressed the father's supportive role was to enable mothers to continue to breastfeed. ${ }^{94}$

Ironically, the attempt to meet the baby's emotional needs through demand feeding further undermined breastfeeding. Yet in 1950s New Zealand, Plunket nurses who continued to promote breastfeeding and "flexible routines", were sometimes regarded as old fashioned. Mothers turned to their doctors and to Spock.

\section{Medicalization of Breastfeeding}

Rima Apple has argued that doctors in America oversaw the transfer from breast to bottle as part of the medicalization of infant feeding. Responsibility and control of the process were transferred from mothers to health professionals, and infant feeding was redefined as a process requiring professional guidance and expertise. Medicalization of infant feeding occurred in post-war Britain and to a lesser extent in New Zealand, though not in relation to bottle feeding. Rather, breastfeeding itself was medicalized, and this possibly contributed to its decline. Breastfeeding was perceived as a mechanistic process, liable to breakdown but which could also be medically controlled.

As early as 1939 Dr James Spence argued that the decline in the number of women leaving hospital fully breastfeeding was due to the "mismanagement of the mother before and during the lying-in period". He explained that breastfeeding had come to be regarded too much as a highly technical procedure which only a few women could be expected to perform. The mother should cultivate an instinctive recognition of her own baby's needs and learn to recognize its appetites and desires. ${ }^{95}$ Yet his own talk of "mismanagement of the mother" heralded a new medicalization of the breast and of breastfeeding which gained momentum in the post-war period-this was the study of "hypogalactia", or inadequate secretion of breast milk. When Dr D Brewer advised, "When you get a healthy young pregnant woman coming to you at the ante-natal clinic ... leave the breasts alone", he was not alluding to any sexual harassment but to the new methods of promoting breastfeeding. ${ }^{96}$ These were introduced by Dr Harold Waller of the Woolwich Hospital for Mothers and Babies, who became a widely cited authority on breastfeeding, in New Zealand as well as Britain. Waller believed that failure to establish breastfeeding was a result of an anatomical defect of the nipple which affected about 40 per cent of all women. ${ }^{97}$ The problem, as explained by Dr B D R Wilson from St Thomas' Hospital in a paper called 'Encouraging natural feeding', was the so-called "attached" nipple. This could be diagnosed when pressure of the fingers on the areola caused the nipple to retract as if attached to deeper tissue rather than stand out, which was the normal reaction. Treatment involved digital manipulation but if that did

\footnotetext{
${ }^{94}$ Modern Mothercraft, Official Handbook, Royal New Zealand Society for the Health of Women and Children, 2nd ed., Dunedin, 1953, p. 63.

${ }^{95} \mathrm{~J}$ C Spence, 'The encouragement of breast feeding', Mother and Child, Aug. 1939, 10 (5): 169-72, p. 171.
}

\footnotetext{
${ }^{96} \mathrm{D}$ Brewer, in discussion following sesson on 'The encouragement of breast feeding', Mother and Child, Aug. 1939, 10 (5): 183.

${ }^{97} \mathrm{~K}$ H Waller, 'The importance of breast feeding', Mother and Child, Aug. 1952, 23 (5): 126-7, p. 127.
} 
not work Waller had invented a glass nipple shell to be worn during pregnancy to stretch the nipple. He also advised breast massage and manual expression of breast milk (as a kind of dress rehearsal) from the thirty-second week of pregnancy. Finally, as Wilson explained, sedatives might be needed when the time came to start feeding! ${ }^{98}$ With such a complex process, it is hardly surprising that some women were deterred. Waller produced excellent results, however, with 83 per cent still breastfeeding by six monthswhich was probably due to the individual care and attention lavished on the women rather than to his technical intervention. As Helen Deem noted, he and his staff made the women feel important. ${ }^{99}$ Yet, referring to Waller's success, Wilson commented on "what can be achieved by an efficient and co-operative team". ${ }^{100}$ It was no longer a personal matter between mother and baby.

Following Waller, Dr Mavis Gunther from the Obstetrics Hospital, University College London, also advised in 1955 that, "Although most breasts usually improve during pregnancy it is wiser to treat than to leave untreated those about whom there is any doubt". She explained that in animals artificial stimuli could be more effective than the natural ones, using the example that if an oyster catcher were offered her own eggs or wooden ones twice the size, it sat on the wooden ones. "In the same way," she said, "it seems that a bottle teat is sometimes 'super-normal' to a poorly formed breast and where the mother's breast is not fully protractile the baby will fall in love with and only respond to the bottle teat". ${ }^{101}$

\section{Other Explanations given for the Post-War Decline in Breastfeeding}

By 1961 only 12 per cent of mothers in Britain still breastfed at six months, and 40 per cent of all babies had been weaned by the age of two weeks. Mother and Child commented that old concepts of infant feeding had been discarded. It explained, "the hallowed precept that breast milk is the best food for all new-born babies and especially for premature infants can no longer be maintained. There is convincing evidence that premature infants fed on suitable cow's milk formulae grow faster than, and resist infection as well as, those ... on human milk". ${ }^{102}$ Breastfeeding in Britain and New Zealand, as well as in America, seemed to be headed for extinction. ${ }^{103}$ This was noted in a 1965 World Health Organization report which stated that breastfeeding in developed countries had dropped to 20 per cent or less, and commented, "Though this situation is regretted by some people, it does not seem to have had undesirable results". ${ }^{104}$

\footnotetext{
${ }^{98}$ B D R Wilson, 'Encouraging natural feeding', Mother and Child, May 1951, 22 (2): 27-30, p. 29. See also Desmond O Oliver, 'Ante-natal breast care at Queen Mary Maternity Hospital', Public Health thesis, University of Otago, 1954.

${ }^{99}$ Plunket Society, Report of Twenty-ninth General Conference, 1948, p.15.

${ }^{100}$ Wilson, op. cit., note 98 above, p. 27.

${ }^{101}$ Mavis Gunther, 'Feeding in the first days', Mother and Child, July 1955, 26 (4): 102-7, pp. 103-4.
}

\footnotetext{
102 'Commentary', Mother and Child, Nov. 1961, 32 (8): 187; also refers to The Times, 6 September 1961, Medical Research Council, Special Report Series 296, 1959.

${ }^{103}$ Grace H Walker,'Some reflections on the decline of breast feeding', Mother and Child, June 1942, 13 (3): 46-8, p. 46.

${ }^{104}$ World Health Organization Report, 'Nutrition in pregnancy and lactation', Mother and Child, Oct. 1965 , p. 17.
} 


\section{Linda Bryder}

Some commentators argued at the time that the movement of mothers into the workforce was important in the post-war decline of breastfeeding. In New Zealand in 1945 married women made up 17.2 per cent of the total female paid workforce, a figure which had risen to 41.5 per cent by $1966 .{ }^{105}$ Yet a 1963 study of twenty Christchurch mothers did not find that the wish to return to work was a factor influencing the decision to breastfeed. ${ }^{106}$ Similarly a 1972 study found that only one per cent of mothers stopped breastfeeding in order to return to work. ${ }^{107}$ Studies in Britain demonstrated that the trend was spread across the socio-economic scale and not confined to working mothers.

Evolution was evoked in the 1950s to explain the decline and even the continuation of breastfeeding. The journal Mother and Child devoted a special issue to breastfeeding in 1955, explaining that it was "still a topic of very general interest". The editorial stated, "It seems an obvious, though frequently forgotten, fact that although the human race has lost certain characteristics during the course of its evolution-the tail is a striking example of this - the human female still retains the power of lactation. It would appear therefore that the physiological and most suitable food for the human infant is still breast milk." 108 Yet one medical officer of health in England wondered whether the "fairly common occurrence of flat and depressed nipples was a sign of degeneration". He considered that maybe the baby on the bottle might be a distant prelude to the baby in the bottle. ${ }^{109}$

The modern cultural definition of the breast as a sexual organ was also invoked as a possible factor. An American psychiatrist wrote somewhat fancifully of the conflict regarding the functioning of the breast, since it was a sexual organ with the same psychological value in the female as attributable to the penis in the male. "The act of nursing would, therefore," he wrote, "be regarded by some women as a castration threat." He also found breastfeeding more common among those in his sample he had labelled "primitive". ${ }^{110}$ Such medical attitudes may have reinforced young women's negative stereotypes about breastfeeding despite the efforts of such groups as La Leche League (set up in Chicago in 1957) and the Maternity Center of New York to reclaim it. Another American study, published in Clinical Obstetrics and Gynaecology in 1962, argued that a culture which tended to minimize differences between men and women was not likely to encourage breastfeeding. "It is not surprising that the small-hipped, shorthaired woman in slacks who is now considered to be in the height of fashion should carry her desire to be manlike one step further" and decline to breastfeed. ${ }^{111}$ Feminists from the 1970s interpreted the women's movement differently and breastfeeding

\footnotetext{
${ }^{105}$ Melanie Nolan, Breadwinning: New Zealand women and the state, Christchurch, Canterbury University Press, 2000, p. 220.

${ }^{106}$ M J Kral, 'The decline of breast feeding', Public Health thesis, University of Otago, 1963, pp. 33-4.

${ }^{107}$ Lynley J Hood, Julia A Faed, P A Silva, Patricia M Buckfield, 'Breast feeding and some reasons for electing to wean the infant: a report from the Dunedin Multidisciplinary Child Development Study', NZMJ, 1978, 88: 273-6, p. 275.
}

\footnotetext{
${ }^{108}$ Editorial, Mother and Child, July 1955, 26 (4): 87.

${ }^{109}$ Walker, op. cit., note 103 above, p. 47.

${ }^{110}$ Justin D Call, from the Department of Psychology, UCLA Medical School, 'Emotional factors causing successful breastfeeding of infants', J. Pediatr., 1959, 55: 485-93.

${ }^{111}$ Michael Newton and Niles Newton, 'The normal course and management of lactation', Clinical Obstetrics and Gynaecology, 1962, 5 (1): 52.
} 
again became fashionable, as women sought to reclaim their bodies from the medical profession.

It was found in a New Zealand study that the proportion of all mothers breastfeeding increased from 62 per cent in 1972 to 82 per cent in 1978, and the median length of time of breastfeeding also increased from five weeks in 1972 to seventeen weeks in $1978 .^{112}$ In 1976 Truby King's daughter, Mary White, commented happily to the British paediatrician Hugh Jolly that breastfeeding was again becoming the fashion. ${ }^{113}$ As Jacqueline Wolf noted, activists in the women's movement encouraged women to learn about and trust their bodies and take responsibility for their own health, with feminists arguing that natural childbirth and breastfeeding were two ways "to take from the largely male medical profession what should have been the sole prerogative of women all along". 114

\section{Conclusion}

This study has discussed different attitudes to breastfeeding among health professionals in America, Britain and New Zealand, and changing attitudes over time. It has found that these differences were reflected in their respective breastfeeding rates. In America, bottle-feeding, as Rima Apple has argued, appeared to be an accepted part of medically-directed childrearing. By contrast, doctors in Britain and New Zealand continued to support breastfeeding, at least until the Second World War. In the post-Second World War period, some paediatricians in Britain tried to medicalize breastfeeding to enhance its success, which may have inadvertently contributed to its decline. Ironically the new psychology of the 1950s and the importance attached to infants' emotional needs, which led to demand feeding, might also have contributed to the decline of breastfeeding. While the association of breastfeeding with the natural childbirth movement perhaps contributed to flagging medical support for breastfeeding in the post-war period, this association eventually persuaded women to reclaim breastfeeding as part of a rejection of medicalized childbirth. Ultimately it was the women who decided. In 1907, when breastfeeding rates were thought to be low, Dr William Collins, a London-trained doctor working in New Zealand, complained that many women objected to breastfeeding, no matter how much the doctor urged it. ${ }^{115}$ By 1913 middle-class women in New Zealand considered it "bad form" not to breastfeed. ${ }^{116}$ In 1962, when rates were again on the decline, Janet Mackay, Plunket's Director of Nursing Services, regretted that at the present time women "just don't want it". ${ }^{117}$ Yet, also important was which group of professionals had the women's confidence; in America it appeared to be their doctors, in

\footnotetext{
${ }^{112}$ Janette Briggs and Bridget Bridget, Maternal and infant care in Wellington 1978: a health care consumer study in replication, Department of Health Special Report Series 64, Wellington, Government Printer, 1983, p. 56; Hood, et al., op. cit., note 107 above, pp. 273-6.

${ }^{113}$ Mary White to Hugh Jolly, 4 May 1976, GC/143/12/2, Wellcome Library, Manuscripts and Archives.
}

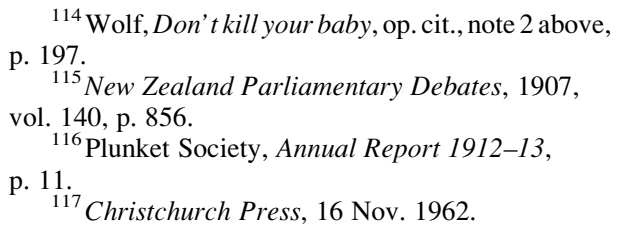




\section{Linda Bryder}

pre-Second World War New Zealand it was the Plunket nurses, while in the immediate post-war period it was their doctors and the American doctor, Benjamin Spock. Prior to the Second World War the Mothercraft Training Society in Britain and the Plunket Society in New Zealand received and published many appreciative letters from women who had been helped and supported by nurses in attempting to breastfeed. The support, or lack of support, from health professionals appeared to play a key role in the success or otherwise of breastfeeding. 